\title{
Improved HTGTS for CRISPR/Cas9 Off-target Detection
}

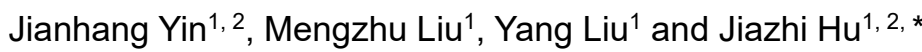

${ }^{1}$ The MOE Key Laboratory of Cell Proliferation and Differentiation, Genome Editing Research Center, School of Life Sciences, Peking University, Beijing, 100871, China; ${ }^{2}$ Peking-Tsinghua Center for Life Sciences, Peking University, Beijing, 100871, China

*For correspondence: $\underline{\text { hujz@pku.edu.cn }}$

\begin{abstract}
[Abstract] Precise genome editing is essential for scientific research and clinical application. At present, linear amplification-mediated high-throughput genome-wide translocation sequencing (LAM-HTGTS) is one of most effective methods to evaluate the off-target activity of CRISPR-Cas9, which is based on chromosomal translocation and employs a "bait" DNA double-stranded break (DSB) to capture genomewide "prey" DNA DSBs. Here, we described an improved HTGTS (iHTGTS) method, in which sizeselection beads were used to enhance reaction efficiency and a new primer system was designed to be compatible with Illumina Hiseq sequencing. Compared with LAM-HTGTS, iHTGTS is lower cost and has much higher sensitivity for off-target detection in HEK293T, K562, U2OS and HCT116 cell lines. So we believe that iHTGTS is a powerful method for comprehensively assessing Cas 9 off-target effect.
\end{abstract}

Keywords: CRISPR-Cas9, Off-target activity, Chromosomal translocation, LAM-HTGTS, iHTGTS

[Background] The CRIPSR-Cas9 (clustered regularly interspaced short palindromic repeats and CRISPR-associated proteins) has been widely used as a powerful genome editing tool (Cong et al., 2013; Jinek et al., 2013; Mali et al., 2013). However its off-target activity causes DNA DSBs at imperfectly matched loci. During the past few years, several methods based on next-generation sequencing have been published to detect off-target sites. LAM-HTGTS (Frock et al., 2015; Hu et al., 2016), which is based on chromosomal translocation, makes use of a "bait" DSB to capture "prey" DSBs to sensitively identify off-target hotspots; GUIDE-seq inserts a specific DNA oligo into break site and applies PCR to enrich DSBs (Tsai et al., 2015). In vitro methods such as Digenome-seq (Kim et al., 2015) and CIRCLEseq (Tsai et al., 2017) are more sensitive but often need to be verified in vivo. Though LAM-HTGTS is very sensitive, there is still room for improvement.

In the improved HTGTS (iHTGTS), we applied size-selection beads to deplete surplus biotinylated primer for the bridge adapter ligation efficiency enhancement. iHTGTS showed 4 times greater sensitivity than LAM-HTGTS. Also a new primer system was employed which can accommodate $150 \mathrm{bp} \times 2$ Hiseq sequencing instead of $250 \mathrm{bp} \times 2$ Miseq, so that the sequencing cost is much saved. Taken together, iHTGTS is a cost-effective and high efficient method. We believe iHTGTS can give researchers deeper insights into the off-target activity of CRIPSR/Cas9. 


\section{Materials and Reagents}

1. Pipette tips (Quality Scientific Plastics)

2. $1.5 \mathrm{ml}$ tube (Axygen, catalog number: MCT-150-C)

3. $0.22 \mu \mathrm{m}$ syringe filter (MILLEX, catalog number: PR03683)

4. $200 \mu \mathrm{l} \mathrm{PCR}$ tubes (Axygen, catalog number: 14-222-261)

5. Agarose (Thermo Fisher, catalog number: R0492)

6. $1 \mathrm{~kb}$ DNA plus ladder (Transgen Biotech, catalog number: BM211)

7. Streptavidin $\mathrm{C} 1$ beads (Thermo Fisher, catalog number: 65001)

8. AMPure XP beads (Axygen)

9. Protease K (Sigma, catalog number: P8044)

10. FastPfu (Transgen Biotech, catalog number: AP221-02)

11. dNTPs (Transgen Biotech, catalog number: AD101-11)

12. AxyPrep MAG PCR Clean-Up (Axygen, catalog number: MAG-PCR-CL)

13. $\mathrm{NaCl}$ (VWR Life Sciences, catalog number: 97061-266)

14. EDTA (Amresco, catalog number: BDH9232)

15. Tris (VWR Life Sciences, catalog number: 97062-420)

16. PEG 8000 (Sigma, catalog number: 89510-250G-F)

17. T4 ligase (Thermo Fisher, catalog number: EL0011)

18. EasyTaq (Transgen Biotech, catalog number: AP111-01)

19. Gel extraction kit (Thermo Fisher, catalog number: K0691)

20. $75 \%$ Ethanol (Beijing Chemical Works)

21. Isopropyl (Beijing Chemical Works)

22. EDTA- $\mathrm{Na}_{2} \cdot 2 \mathrm{H}_{2} \mathrm{O}$ (Amresco, catalog number: $\mathrm{BDH} 9232$ )

23. $\mathrm{NaOH}$ (Sigma, catalog number: 221465)

24. $\mathrm{HCl}$ (Sigma, catalog number: 7647-01-0)

25. SDS (Sigma, catalog number: 72455)

26. TAE (see Recipes)

27. Proteinase $K$ (see Recipes)

28. $5 \mathrm{M} \mathrm{NaCl}$ (see Recipes)

29. 0.5 M EDTA ( $\mathrm{pH}$ 8.0) (see Recipes)

30. $1 \mathrm{M}$ Tris- $\mathrm{HCl}$ ( $\mathrm{pH} 7.4$ ) (see Recipes)

31. Cell lysis buffer (see Recipes)

32. TE buffer (see Recipes)

33. $50 \%$ (wt/vol) PEG 8000 (see Recipes)

34. $2 \times$ B\&W buffer (see Recipes)

35. Annealing buffer (see Recipes)

36. $50 \mathrm{mM}$ bridge adapter (see Recipes) 


\section{Equipment}

1. Foam floating tube rack

2. 8-well magnet stand

3. Pipettes (GILSON)

4. Thermomixer $C$ (Eppendorf)

5. PCR Thermal Cyclers (Applied Biosystems)

6. Covaris (M220 Focused-ultrasonicator)

7. Centrifuge (Eppendorf, model: $5418 \mathrm{R}$ )

8. NanoDrop (DeNOVIX, DS11)

9. Incubator (Thermo Fisher)

10. Autoclave

\section{Procedure}

A. Design the primers used for iHTGTS

Choose Cas9-generated on-target site DSB as the "bait" to capture other genome-wide "prey" DSBs. To be compatible with $2 \times 150$ bp Hiseq sequencing, biotinylated primer for LAM-PCR was designed to bind 150 bp upstream of Cas9 binding site; nested primer was designed annealling to the downstream of the biotinylated primer about 90 bp away from the cut site. (Figure 1, Table 1) Note: Avoid designing primers at DNA repetitive region.

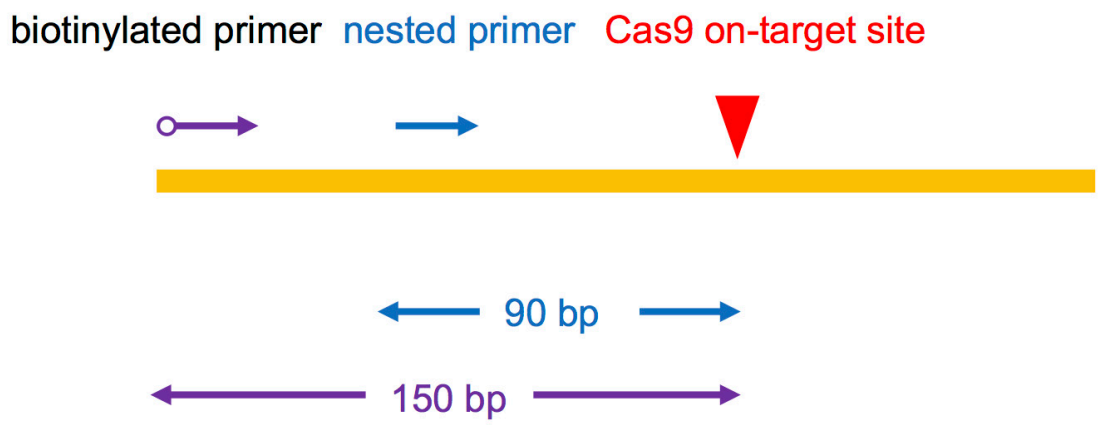

Figure 1. Primer design for iHTGTS. The red arrow indicates the Cas 9 on-target cutting site. The blue arrow indicates the nested primer and purple indicates the biotinylated primer. The distance to the cutting site is shown below. 
Table 1. The sequences of primers and bridge adapters. The Phor indicates the phosphorylation. MID indicates the index base for data demultiplex. REDPRIMER indicates nested primer, which varies between different loci.

\begin{tabular}{ll}
\hline Adapter-upper-6N & TGTAGAGCACGCGTGGNNNNNN-NH2 \\
Adapter-lower-NH2 & /5Phor/CCACGCGTGCTCTACAAGATCGGAAGAGCACACGTCTGAAC \\
& TCCAGT-NH2 \\
P5-15 & AATGATACGGCACCACCGAGATCTACACACACTCTTTCCCTACACG \\
P7-17 & ACGC \\
15-Red & CAAGCAGAAGACGGCATACGAGAT \\
17-Blue & ACTCTTTCCCTACACGACGCTCTTCCGATCTMIDREDPRIMER \\
\hline
\end{tabular}

\section{B. Extract Genomic DNA (gDNA)}

1. Forty-eight hours after transfecting HEK293T cells with the Cas9 plasmids, collect $10^{7}$ transfected HEK293T cells (we have also tried K562, HCT116 and U2OS, all work well) in a $1.5 \mathrm{ml}$ tube and add $500 \mu \mathrm{l}$ cell lysis buffer. Incubate the tube in Thermomixer at $56{ }^{\circ} \mathrm{C}, 500 \times \mathrm{g}$ for $10-18 \mathrm{~h}$.

Note: Protease $K$ solution should be added into lysis buffer just before use $(10 \mathrm{ng} / \mathrm{ml}$ final concentration).

2. Add $500 \mu \mathrm{l}$ isopropyl and mix thoroughly till you can see a white flocculent DNA pellet.

3. Using a pipet to transfer the pellet into another $1.5 \mathrm{ml}$ tube with $1 \mathrm{ml} 70 \%$ ethanol. Centrifuge at $13,000 \times g$ for $5 \mathrm{~min}$.

4. Discard the supernatant. Centrifuge again and deplete residual $70 \%$ ethanol. Add $500 \mu \mathrm{ITE}$ and incubate the tube in Thermomixer at $56^{\circ} \mathrm{C}, 500 \times \mathrm{g}$ for at least $2 \mathrm{~h}$.

Note: Adjust the volume of added TE to make sure the DNA concentration not less than $200 \mathrm{ng} / \mu \mathrm{l}$.

5. Quantify the DNA using NanoDrop. The $A_{260} / A_{280}$ should be higher than 1.8.

6. Recommend $20 \mu \mathrm{g}$ gDNA for iHTGTS library construction.

C. Fragment gDNA by sonication

1. Add $20 \mu \mathrm{g}$ gDNA into a PCR tube. Set Covaris with the following parameters: PIP $=50$ watts, $\mathrm{DF}=30 \%, \mathrm{CPB}=200$, Time $=60 \mathrm{~s}$

2. After sonication, take $200 \mathrm{ng}$ DNA for $1 \%$ agarose page. The range of the DNA smear should be at $0.2-2 \mathrm{~kb}$ with a peak at $0.75 \mathrm{~kb}$. (Figure 2) 


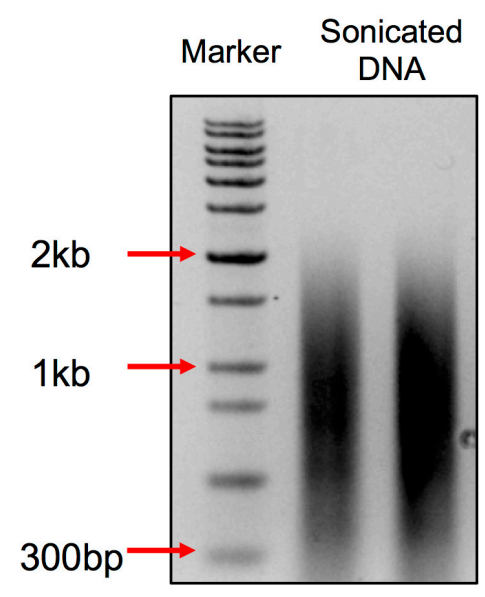

Figure 2. DNA smear pattern after sonication. The smear ranges from $300 \mathrm{bp}$ to $2 \mathrm{~kb}$ with the peak at about $750 \mathrm{bp}$.

\section{LAM-PCR}

1. Set up the reaction in $4 \times 50 \mu \mathrm{ICR}$ tubes as following (DNA template for each PCR reaction can be 1-10 $\mu \mathrm{g})$ :

\begin{tabular}{lll}
\hline & $1 \times(\mu \mathrm{l})$ & $4 \times(\mu \mathrm{l})$ \\
\hline 5x FastPfu buffer & 10 & 40 \\
dNTPs $(2.5 \mathrm{mM})$ & 1.5 & 6 \\
Bio-primer $(1 \mu \mathrm{M})$ & 0.5 & $2(1 \mu \mathrm{M})$ \\
FastPfu & 0.5 & 2 \\
Sonicated DNA & 25 & 100 \\
$\mathrm{H}_{2} \mathrm{O}$ & 12.5 & 50 \\
\hline
\end{tabular}

2. Set up the PCR program:

$95^{\circ} \mathrm{C}$ for $2 \mathrm{~min}$

$\left[95^{\circ} \mathrm{C}\right.$ for $30 \mathrm{~s}, 58^{\circ} \mathrm{C}$ for $30 \mathrm{~s}, 72^{\circ} \mathrm{C}$ for $1.5 \mathrm{~min}$ ] (80 cycles)

$72{ }^{\circ} \mathrm{C}$ for $2 \mathrm{~min}$

$10^{\circ} \mathrm{C}$ forever

3. Deplete surplus biotin primer using AMPure XP beads

a. Add $50 \mu \mathrm{l}$ AMPure XP beads into each PCR tube, mix gently and incubate the tubes at RT for 5 min.

Note: This step aims to remove fragments less than $300 \mathrm{bp}$; the volume of the beads can be upscaled according to different batches.

Note: All the following Steps (D3b-D3f) are operated at RT.

b. Put the tubes on an 8-well magnet stand for $5 \mathrm{~min}$.

c. Remove the supernatant, add $200 \mu \mathrm{l} 70 \%$ ethanol. After standing for $30 \mathrm{~s}$, remove the supernatant. 
d. Repeat the Step D3c.

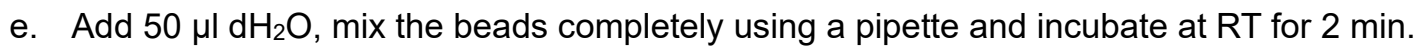

f. Put the tubes on the magnet for $2 \mathrm{~min}$ and pool the supernatants (about $200 \mu \mathrm{l}$ ) into a new $1.5 \mathrm{ml}$ tube.

E. Streptavidin beads binding

1. Add $50 \mu \mathrm{l} 5 \mathrm{M} \mathrm{NaCl}, 2.5 \mu \mathrm{l} 0.5 \mathrm{M}$ EDTA into the PCR product from the last step. Add $30 \mu \mathrm{l}$ streptavidin beads and rotate for $4 \mathrm{~h}$ at RT. (The streptavidin beads should be washed twice with 1x B\&W buffer before use)

2. Put the beads against the $1.5 \mathrm{ml}$ tube magnet stand and remove the supernatant. Wash the beads three times each using $400 \mu \mathrm{l} 1 \mathrm{x}$ B\&W buffer.

3. Wash the beads with $400 \mu \mathrm{ldH} \mathrm{H}_{2} \mathrm{O}$ and then resuspend the beads in $42.4 \mu \mathrm{dH}_{2} \mathrm{O}$.

F. On-beads ligation for bridge adapter

\begin{tabular}{ll}
\hline & $1 \times(\mu \mathrm{l})$ \\
\hline 10x T4 DNA ligase buffer & 8 \\
Bridge adapter $(50 \mu \mathrm{M})$ & 1.6 \\
T4 DNA ligage $(5 \mathrm{U} / \mu \mathrm{l})$ & 4 \\
50\% (wt/vol) PEG8000 & 24 \\
DNA-beads complex & 42.4 \\
\hline Total & 80
\end{tabular}

Set the reaction in a $1.5 \mathrm{ml}$ tube in a rotator and ligate overnight at $\mathrm{RT}$.

G. Nested PCR

1. Add $80 \mu \mathrm{l} 2 \times \mathrm{x} \& W$ buffer and $160 \mu \mathrm{l} 1 \times \mathrm{x} \& W$ buffer. Put the beads against the $1.5 \mathrm{ml}$ tube magnet stand and remove the supernatant. Wash the beads using $400 \mu \mathrm{l} 1 \mathrm{x} B \& W$ buffer three times and $400 \mu \mathrm{ldH} \mathrm{H}_{2} \mathrm{O}$ once. Resuspend the beads in $80 \mu \mathrm{ld} \mathrm{d}_{2} \mathrm{O}$.

2. Set up the $P C R$ reaction in $2 x P C R$ tubes as following:

\begin{tabular}{lll}
\hline & 1x $(\mu \mathrm{l})$ & $2 \times(\mu \mathrm{l})$ \\
\hline 10x EasyTaq PCR buffer & 5 & 10 \\
dNTPs $(2.5 \mathrm{mM})$ & 4 & 8 \\
I5-Red $(10 \mu \mathrm{M})$ & 2 & 4 \\
17-Blue $(10 \mu \mathrm{M})$ & 2 & 4 \\
EasyTaq polymerase & 0.5 & 1 \\
DNA-beads complex & 40 & 80 \\
\hline
\end{tabular}

3. Set up the PCR program:

$95^{\circ} \mathrm{C}$ for $5 \mathrm{~min}$

[95 ${ }^{\circ} \mathrm{C}$ for $1 \mathrm{~min}, 58^{\circ} \mathrm{C}$ for $30 \mathrm{~s}, 72^{\circ} \mathrm{C}$ for $1 \mathrm{~min}$ ] ( 15 cycles) 

$72^{\circ} \mathrm{C}$ for $10 \mathrm{~min}$
$10^{\circ} \mathrm{C}$ forever

4. Recycle the PCR products using AMpure XP beads as described in Step D3. Elute the PCR

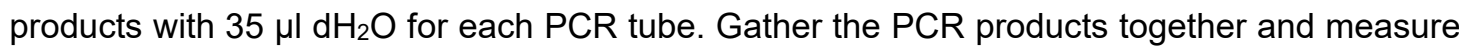
the concentration.

Note: This step aims to remove DNA fragments less than $500 \mathrm{bp}$, upscale the volume of the beads according to different batches.

\section{Enzyme Blocking (Optional)}

1. Add $8 \mu \mathrm{l} 10 \mathrm{x}$ enzyme buffer, $10 \mathrm{U}$ blocking enzyme, incubate at $37^{\circ} \mathrm{C}$ for $1 \mathrm{~h}$ or longer.

2. Purify the DNA with GeneJET column, elute with $70 \mu \mathrm{ld} \mathrm{d}_{2} \mathrm{O}$, and check the concentration.

H. Tagged PCR

1. Set up the PCR reaction in $2 \times P C R$ tubes as following:

\begin{tabular}{lll}
\hline & $1 \times(\mu \mathrm{l})$ & $2 \times(\mu \mathrm{l})$ \\
\hline 5x FastPfu PCR buffer & 10 & 20 \\
dNTPs $(2.5 \mathrm{mM})$ & 4 & 8 \\
P5-I5 $(10 \mu \mathrm{M})$ & 2 & 4 \\
P7-17 $(10 \mu \mathrm{M})$ & 2 & 4 \\
FastPfu polymerase & 0.5 & 1 \\
DNA & 35 & 70 \\
\hline
\end{tabular}

2. Set up the PCR program:

$95^{\circ} \mathrm{C}$ for $3 \mathrm{~min}$

$\left[95^{\circ} \mathrm{C}\right.$ for $20 \mathrm{~s}, 60^{\circ} \mathrm{C}$ for $30 \mathrm{~s}, 72^{\circ} \mathrm{C}$ for $\left.1 \mathrm{~min}\right](10-15$ cycles $)$

$72{ }^{\circ} \mathrm{C}$ for $5 \mathrm{~min}$

$10{ }^{\circ} \mathrm{C}$ forever

Note: The PCR cycle number is dependent on the DNA concentration from the last step.

\begin{tabular}{|c|c|c|}
\hline $\begin{array}{l}\text { DNA concentration }(\mathrm{ng} / \mu \mathrm{l}) \text { (no } \\
\text { enzyme blocking) }\end{array}$ & $\begin{array}{l}\text { DNA concentration }(\mathrm{ng} / \mu \mathrm{l}) \\
\text { (enzyme blocking) }\end{array}$ & Cycle number \\
\hline$>15$ & $>10$ & 11 \\
\hline $10-15$ & $7-10$ & $12-13$ \\
\hline$<10$ & $<7$ & $14-16$ \\
\hline
\end{tabular}

I. Purified PCR products

Pool the DNA together, run all the DNA on $1 \%$ agarose gel in TAE buffer, cut products between 500 900 bp (Figure 3), purify through a Gel extraction column, elute with $30 \mu \mathrm{ld} \mathrm{d}_{2} \mathrm{O}$ twice. Now the PCR product is ready for Hiseq sequencing. 


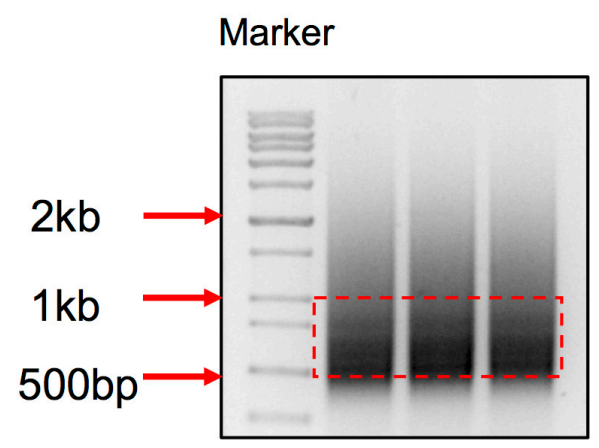

Figure 3. DNA smear pattern for iHTGTS library. Cut the DNA within the range from $500 \mathrm{bp}$ to $1 \mathrm{~kb}$.

\section{Data analysis}

The detailed operation and mechanism for data analysis is the same with LAM-HTGTS, which can be found in the step 48 to step 51 for Hu et al. (2016).

\section{$\underline{\text { Recipes }}$}

Note: The reagents used in this protocol are almost the same with those in Hu et al. (2016). The following recipes are adapted from it.

1. TAE

$40 \mathrm{mM}$ Tris- $\mathrm{HCl}$

$20 \mathrm{mM}$ Acetic Acid

1 mM EDTA

2. Proteinase $\mathrm{K}$

Dissolve $0.1 \mathrm{~g}$ of proteinase $\mathrm{K}$ powder in $5 \mathrm{ml}$ of $\mathrm{H}_{2} \mathrm{O}$ to make a $20 \mathrm{mg} / \mathrm{ml}$ stock

Divide the solution into $0.5 \mathrm{ml}$ aliquots and store them at $-20^{\circ} \mathrm{C}$ for up to 3 months

3. $5 \mathrm{M} \mathrm{NaCl}$

Dissolve $292.5 \mathrm{~g}$ of $\mathrm{NaCl}$ in $\mathrm{H}_{2} \mathrm{O}$, and adjust the total volume to $1 \mathrm{~L}$

Autoclave the solution and store it at room temperature (RT; $\left.20-25^{\circ} \mathrm{C}\right)$ for up to 1 year

4. $0.5 \mathrm{M}$ EDTA ( $\mathrm{pH} 8.0)$

Dissolve $186.12 \mathrm{~g}$ of EDTA- $\mathrm{Na}_{2} \cdot 2 \mathrm{H}_{2} \mathrm{O}$ in $\mathrm{H}_{2} \mathrm{O}$, adjust the $\mathrm{pH}$ to 8.0 using $2.5 \mathrm{~N} \mathrm{NaOH}$ and then adjust the total volume to $1 \mathrm{~L}$

Autoclave the solution and store it at RT for up to 1 year

5. $1 \mathrm{M}$ Tris- $\mathrm{HCl}(\mathrm{pH} 7.4)$

Dissolve $121.14 \mathrm{~g}$ of Tris base in $\mathrm{H}_{2} \mathrm{O}$, adjust the $\mathrm{pH}$ to 7.4 using $\mathrm{HCl}$, and then bring the total volume to $1 \mathrm{~L}$

Autoclave the solution and store it at RT for up to 1 year

6. Cell lysis buffer 
$200 \mathrm{mM} \mathrm{NaCl}$

$10 \mathrm{mM}$ Tris- $\mathrm{HCl}(\mathrm{pH} 7.4)$

2 mM EDTA (pH 8.0)

$0.2 \%(\mathrm{wt} / \mathrm{vol}) \mathrm{SDS}$

Store it at RT for up to 6 months

7. TE buffer

$10 \mathrm{mM}$ Tris- $\mathrm{HCl}(\mathrm{pH} 7.4)$

$0.5 \mathrm{mM}$ EDTA ( $\mathrm{pH} 8.0$ )

Store it at RT for up to 6 months

8. $50 \%$ (wt/vol) PEG 8000

Dissolve $5 \mathrm{~g}$ of PEG 8000 in $\mathrm{H}_{2} \mathrm{O}$ at $56{ }^{\circ} \mathrm{C}$, and then adjust the total volume to $10 \mathrm{ml}$

Filter the solution through a $0.22 \mu \mathrm{m}$ syringe filter, prepare $1 \mathrm{ml}$ aliquots and store them at $-20^{\circ} \mathrm{C}$ for up to 1 year

9. $2 x B \& W$ buffer

$2 \mathrm{M} \mathrm{NaCl}$

$10 \mathrm{mM}$ Tris- $\mathrm{HCl}(\mathrm{pH} 7.4)$

1 mM EDTA (pH 8.0)

Dilute it with $\mathrm{H}_{2} \mathrm{O}$ to make $1 \times \mathrm{B} \& W$ buffer. Store it at $\mathrm{RT}$ for up to 1 year

10. Annealing buffer

$25 \mathrm{mM} \mathrm{NaCl}$

$10 \mathrm{mM}$ Tris- $\mathrm{HCl}(\mathrm{pH} 7.4)$

$0.5 \mathrm{mM}$ EDTA ( $\mathrm{pH} 8.0)$

Store it at RT for up to 1 year

11. $50 \mathrm{mM}$ bridge adapter

a. Dissolve the two DNA oligos (Table 1) in annealing buffer to a final concentration of $400 \mu \mathrm{M}$

b. Mix equal volumes of the two dissolved oligos in a new $1.5 \mathrm{ml}$ microtube, put the tube in $1 \mathrm{~L}$ of boiling water with a foam floating tube rack, boil it for $5 \mathrm{~min}$ and then cool it down slowly in water to $\sim 30^{\circ} \mathrm{C}$ on the bench (adapter concentration is $200 \mu \mathrm{M}$ ). Alternatively, the oligos can be annealed on a PCR thermoblock

c. Dilute fourfold (concentration is $50 \mu \mathrm{M}$ ) with $\mathrm{H}_{2} \mathrm{O}$, prepare $100 \mu$ l aliquots and store them at $-20^{\circ} \mathrm{C}$ for up to 2 months

d. Thaw the adapter on ice before use

\section{Acknowledgments}

Thanks for Thousand Talents Plan Youth Program to J. H. and PKU-TSU Center for Life Sciences.

This protocol is adapted from Hu et al. (2016). 


\section{Competing interests}

The authors declare they have no conflict of interest or competing interests.

\section{References}

1. Cong, L., Ran, F. A., Cox, D., Lin, S., Barretto, R., Habib, N., Hsu, P. D., Wu, X., Jiang, W., Marraffini, L. A. and Zhang, F. (2013). Multiplex genome engineering using CRISPR/Cas systems. Science 339(6121): 819-823.

2. Frock, R. L., Hu, J., Meyers, R. M., Ho, Y. J., Kii, E. and Alt, F. W. (2015). Genome-wide detection of DNA double-stranded breaks induced by engineered nucleases. Nat Biotechnol 33(2): 179-186.

3. Hu, J., Meyers, R. M., Dong, J., Panchakshari, R. A., Alt, F. W. and Frock, R. L. (2016). Detecting DNA double-stranded breaks in mammalian genomes by linear amplificationmediated high-throughput genome-wide translocation sequencing. Nat Protoc 11(5): 853-871.

4. Jinek, M., East, A., Cheng, A., Lin, S., Ma, E. and Doudna, J. (2013). RNA-programmed genome editing in human cells. Elife 2: e00471.

5. Kim, D., Bae, S., Park, J., Kim, E., Kim, S., Yu, H. R., Hwang, J., Kim, J. I. and Kim, J. S. (2015). Digenome-seq: genome-wide profiling of CRISPR-Cas9 off-target effects in human cells. Nat Methods 12(3): 237-243, $231 \mathrm{p}$ following 243.

6. Mali, P., Yang, L., Esvelt, K. M., Aach, J., Guell, M., DiCarlo, J. E., Norville, J. E. and Church, G. M. (2013). RNA-guided human genome engineering via Cas9. Science 339(6121): 823-826.

7. Tsai, S. Q., Nguyen, N. T., Malagon-Lopez, J., Topkar, V. V., Aryee, M. J. and Joung, J. K. (2017). CIRCLE-seq: a highly sensitive in vitro screen for genome-wide CRISPR-Cas9 nuclease off-targets. Nat Methods 14(6): 607-614.

8. Tsai, S. Q., Zheng, Z., Nguyen, N. T., Liebers, M., Topkar, V. V., Thapar, V., Wyvekens, N., Khayter, C., lafrate, A. J., Le, L. P., Aryee, M. J. and Joung, J. K. (2015). GUIDE-seq enables genome-wide profiling of off-target cleavage by CRISPR-Cas nucleases. Nat Biotechnol 33(2): 187-197. 